\title{
PHENOLIC AND ALIPHATIC GLUCOSIDES FROM CRYPTOSTEGIA GRANDIFLORA AND CARDIOTONIC ACTIVITY OF CRYPTOSTIGMIN II
}

\author{
M. H. Assaf, M. S. Kamel, D.W. Bishay
}

Department of Pharmacognosy, Faculty of Pharmacy, Assiut University, Assiut 71526, Egypt

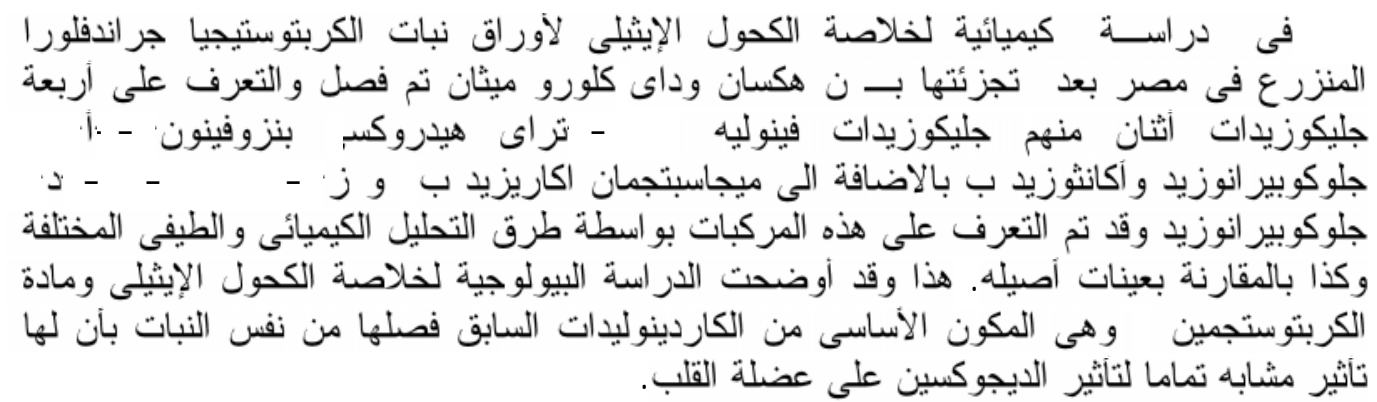

From the leaves of Cryptostegia grandiflora, two phenolic glucosides 2,4,6trihydroxybenzophenone 2-O- $\beta$-glucopyranoside and Acanthoside $B$ together with $a$ megastigmane (Icariside B1) and (Z)-3-hexenyl $\beta$-D-glucopyranoside have been isolated. Moreover the cardiotonic activities of Cryptostegia extract and Cryptostigmin II, the major cardenolide previously isolated from the same plant leaves were also investigated. The latter showed similar effects to those of Digoxin.

\section{INTRODUCTION}

Cryptostegia grandiflora R.Br. (Asclepiadaceae) is an ornamental plant cultivated in Egypt and warm countries. ${ }^{1-3}$ From its leaves, few cardenolides (cryptograndoside A, B and digitalinum verum) have been already reported. ${ }^{4}$ Recently, six more cardenolides (subalpinosid, 16-O-acetyl-digitalinum verum and cryptostigmin I-IV) have been isolated from the leaves of $C$. grandiflora. ${ }^{5}$ The present study deals with the isolation and structure determination of a benzophenone glucoside together with a lignan glucoside and two aliphatic glucosides from the leaves of $C$. grandiflora in addition to investigation of the cardiotonic activity of the leaves extract and cryptostigmin II previously isolated from this plant.

\section{MATERIAL AND METHODS}

\section{Plant material}

Leaves of C. grandiflora R.Br. (Asclepiadaceae) were collected from the trees cultivated in the Experimental Station of faculty of Agriculture, Assiut University, Assiut, Egypt, in March 1997. The plant was identified by Prof. N. El-Keltawi, Department of Horticulture, Faculty of Agriculture, Assiut University, Assiut, Egypt. A voucher specimen is deposited at the Herbarium of Department of Pharmacognosy, Faculty of Pharmacy, Assiut University, Assiut, Egypt.

\section{General experimental procedures}

${ }^{1} \mathrm{H}$ and ${ }^{13} \mathrm{C}-\mathrm{NMR}$ (TMS as int. standard): $400 \mathrm{MHz}$ and $100 \mathrm{MHz}$ respectively were recorded on a JEOL JNM $\alpha-400$ spectrometer. FAB MS spectra were taken on a JEOL JMSSX 102 spectrometer by direct inlet method at an ionizing voltage of $70 \mathrm{eV}$. Optical rotations were measured with a Union PM-1 digital polarimeter. HPLC: D-ODS-5 column $(20 \mathrm{~mm}$ i.d. $\mathrm{x} 25 \mathrm{~cm}, \mathrm{YMC}$ ) with a Toyo Soda high speed chromatograph HLC-803 D pump and a Tosoh refraction index (RI-8) detector; flow rate of mobile phase $6 \mathrm{ml} / \mathrm{min}$, injection volume $0.8-1.0 \mathrm{ml}$. The solvent system used on 
ODS column was $18 \%$ MeCN. Silica gel 60 Merck (70-230 mesh) and Diaion HP 20 (Mitsubishi) were used for column chromatography. Silica gel 60 precoated plates F-254 and HPTLC using RP-18 precoated plates, F-254 s (Merck) were used for TLC analysis.

\section{Extraction and Isolation}

The air-dried powdered leaves of $C$. grandiflora $(500 \mathrm{mg})$ were extracted with $70 \%$ EtOH. The dried ethanolic extract $(125 \mathrm{~g})$ was suspended in $\mathrm{H}_{2} \mathrm{O}$ and defatted successively with n-hexane and $\mathrm{CH}_{2} \mathrm{Cl}_{2}$. The aq. fr. was applied to a column of Diaion HP-20 and eluted with $\mathrm{H}_{2} \mathrm{O}, 40 \% \mathrm{MeOH}, 80 \% \mathrm{MeOH}$, $\mathrm{MeOH}$ and acetone successively. The $40 \%$
$\mathrm{MeOH}$ eluate was chromatographed by silica gel $\mathrm{CC}$ using $\mathrm{CH}_{2} \mathrm{Cl}_{2}-\mathrm{MeOH}-\mathrm{H}_{2} \mathrm{O}$ (75:25:2) and finally with (65:35:5) to give 7 fractions. Fraction 1 (1.66 g) was separated on silica gel column using $\mathrm{CH}_{2} \mathrm{Cl}_{2}-\mathrm{MeOH}-\mathrm{H}_{2} \mathrm{O}$ (85:15:1 65:35:5) and HPLC using ODS column with $18 \% \mathrm{MeCN}$ to afford compounds 1 (white powder, $20 \mathrm{mg}$ ) and $\mathbf{2}$ (white powder, $11 \mathrm{mg}$ ). Fraction 5 (289 mg) was subjected to HPLC using ODS column and $18 \% \mathrm{MeCN}$ to give compound $\mathbf{3}$ (white powder, $105 \mathrm{mg}$ ). Fraction 7 (87 mg) was separated by HPLC under the same conditions of fractions 1 and 5 to afford compound 4 (white powder, $12 \mathrm{mg}$ ).

A part of the residue obtained from the total ethanolic extract was used for the biological study and had been dissolved in normal saline.<smiles>CC/C=C/CCOC(C)=O</smiles><smiles>O=C(c1ccccc1)c1c(O)cc(O)cc1OC1(O)OC(CO)C(O)C(O)C(O)C1O</smiles>

(3)<smiles>CC(=O)/C=C/C1=C(C)[C@](C)(O)CC(Cl)C1</smiles>

(4)

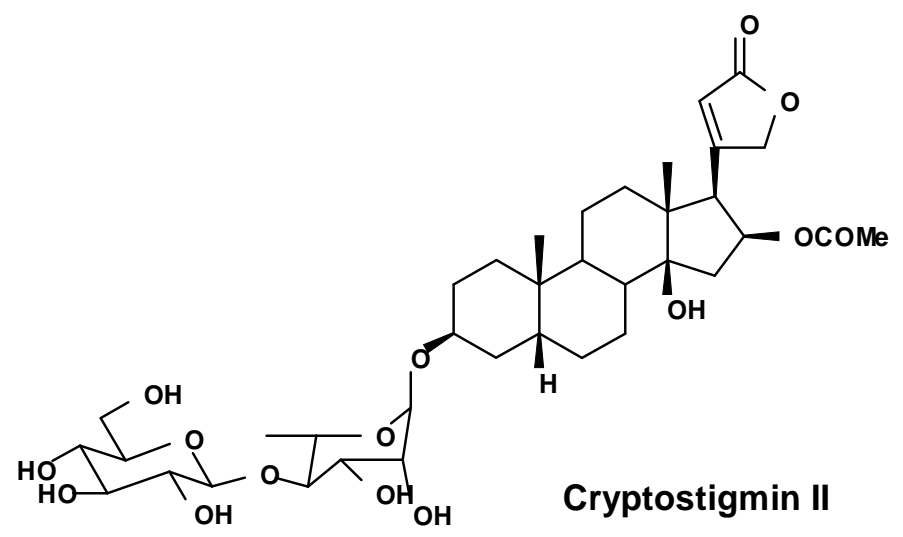


Compound (1): Was obtained as white powder (71 mg), $[\alpha]_{\mathrm{D}}{ }^{25}-25.2^{\circ}(c 0.48, \mathrm{MeOH})$, had the molecular formula $\mathrm{C}_{28} \mathrm{H}_{36} \mathrm{O}_{13}$, negative $\mathrm{FAB}$ MS showed molecular ion peak at $\mathrm{m} / \mathrm{z} 579$ $[(\mathrm{M}-1)]^{-}$and a peak at $\mathrm{m} / \mathrm{z} 417 \quad[(\mathrm{M}-1)-$ glucose $]^{-} .400 \mathrm{MHz}{ }^{1} \mathrm{H}-\mathrm{NMR}\left(\mathrm{C}_{5} \mathrm{D}_{5} \mathrm{~N}\right): \delta 3.79$ (6H, s, 3“, 5“, OMe), 3.82 (6H, s, 3`,5', OMe), $3.92(2 \mathrm{H}, \mathrm{d}, J=2.1,4 \& 8 \beta), 4.22(2 \mathrm{H}, \mathrm{m}, 4$ \& $8 \alpha), 4.96(1 \mathrm{H}, \mathrm{m}, \mathrm{Glc}-1), 6.92(2 \mathrm{H}, \mathrm{s}, 2$ “, $6 “)$, $6.94\left(2 \mathrm{H}\right.$, s, 2', 6) $100 \mathrm{MHz}{ }^{13} \mathrm{C}-\mathrm{NMR}$ $\left(\mathrm{C}_{5} \mathrm{D}_{5} \mathrm{~N}\right)$ as cited in Table 1 .

Compound (2): was obtained as white powder (methanol), $(11 \mathrm{mg}),[\alpha]_{\mathrm{D}}{ }^{17}-33.7^{\circ}(C=0.92$, $\mathrm{MeOH}$ ), had the molecular formula $\mathrm{C}_{12} \mathrm{H}_{22} \mathrm{O}_{6}$,
${ }^{1} \mathrm{H}-\mathrm{NMR}\left(\mathrm{C}_{5} \mathrm{D}_{5} \mathrm{~N}\right): \delta 0.81(3 \mathrm{H}, \mathrm{t}, J=7.6 \mathrm{~Hz}, \mathrm{H}-$ 6), 1.91 (2H b.q, $J=7.2 \mathrm{~Hz}, \mathrm{H}-5), 5.41(2 \mathrm{H}, \mathrm{m}$, $\mathrm{H}-3, \mathrm{H}-4), 2.43(2 \mathrm{H}, \mathrm{b} . \mathrm{q}, J=6.8 \mathrm{~Hz}, \mathrm{H}-2)$ and $4.84(1 \mathrm{H}, \mathrm{d}, J=7.8 \mathrm{~Hz}$, Glc-1). $100 \mathrm{MHz}$ ${ }^{13} \mathrm{C}-\mathrm{NMR}\left(\mathrm{C}_{5} \mathrm{D}_{5} \mathrm{~N}\right)$ as cited in Table 1.

Compound (3): $[\alpha]_{\mathrm{D}}{ }^{17}-67.2^{\circ}$ (c 5.33, MeOH). HRFAB-MS (negative): $\mathrm{C}_{19} \mathrm{H}_{20} \mathrm{O}_{9}-\mathrm{H}$, found: 391.3441 [M-H] calcd: 391.3490. ${ }^{1} \mathrm{H}-\mathrm{NMR}$ (400 MHz, DMSO): $\delta=7.70\left(2 \mathrm{H}, \mathrm{m}, \mathrm{H}-3^{`}, 5^{`}\right)$, $7.56\left(1 \mathrm{H}, \mathrm{m}, \mathrm{H}-4^{\prime}\right), 7.45$ (2H, m, H-2`,6 $), 6.15$ $(1 \mathrm{H}, \mathrm{d}, J=1.9 \mathrm{~Hz}, \mathrm{H}-3), 6.07(1 \mathrm{H}, \mathrm{d}, J=1.9 \mathrm{~Hz}$, $\mathrm{H}-5)$ and $4.74(1 \mathrm{H}, \mathrm{d}, J=7.6 \mathrm{~Hz}, \mathrm{Glc}-1)$. ${ }^{13} \mathrm{C}-\mathrm{NMR} 100 \mathrm{MHz}$ (DMSO) as cited in Table 1.

Table 1: $100 \mathrm{MHz}{ }^{13} \mathrm{C}-\mathrm{NMR}$ data of compounds $\mathbf{1 , 2 , 4}$ in $\left(\mathrm{C}_{5} \mathrm{D}_{5} \mathrm{~N}\right)$ and $\mathbf{3}$ in (DMSO).

\begin{tabular}{|c|c|c|c|c|c|}
\hline C. No. & 1 & 2 & 3 & & 4 \\
\hline $\begin{array}{c}\text { Aglycone } \\
1\end{array}$ & 54.8 & 69.3 & 108.7 & & 36.2 \\
\hline 2 & 86.2 & 28.3 & 157.0 & & 48.0 \\
\hline 3 & & 133.5 & 94.3 & & 71.8 \\
\hline 4 & 72.0 & 125.5 & 160.3 & & 47.0 \\
\hline 5 & 54.7 & 20.8 & 96.7 & & 71.2 \\
\hline 6 & 86.2 & 14.3 & 157.1 & & 119.7 \\
\hline 7 & & & \begin{tabular}{l|l}
$\mathrm{C}=0$ & 194.9 \\
\end{tabular} & & 209.6 \\
\hline 8 & 72.0 & & & & 100.4 \\
\hline 1 & 135.4 & & 138.7 & C-9 & 197.7 \\
\hline 2 & 104.8 & & 128.3 & $\mathrm{C}-10$ & 26.4 \\
\hline 3 & 153.8 & & 129.0 & $\mathrm{C}-11$ & 31.0 \\
\hline 4 & 138.3 & & 132.5 & $\mathrm{C}-12$ & 29.1 \\
\hline 5 & 153.9 & & 129.0 & C-13 & 31.9 \\
\hline 6 & 104.7 & & 128.3 & & \\
\hline $1 "$ & 132.0 & & & & \\
\hline 2 & 104.8 & & & & \\
\hline 3 & 149.2 & & & & \\
\hline 4 & 137.0 & & & & \\
\hline 5 & 149.2 & & & & \\
\hline $6 "$ & 104.7 & & & & \\
\hline $\mathrm{OCH}_{3}$ & $\begin{array}{l}57.0 \\
57.6\end{array}$ & & & & \\
\hline $\begin{array}{c}\beta \text {-glucopyranose } \\
1\end{array}$ & 104.9 & 104.7 & 100.7 & & 103.0 \\
\hline 2 & 75.9 & 75.2 & 73.2 & & 75.4 \\
\hline 3 & 78.2 & 78.5 & 76.6 & & 78.6 \\
\hline 4 & 71.5 & 71.7 & 69.5 & & 71.6 \\
\hline 5 & 78.5 & 78.6 & 77.1 & & 78.3 \\
\hline 6 & 62.5 & 62.8 & 60.7 & & 62.7 \\
\hline
\end{tabular}


Compound (4): was obtained as white powder, $(12 \mathrm{mg}),[\alpha]_{\mathrm{D}}{ }^{17}-60.0^{\circ}(c 1.0, \mathrm{MeOH})$, had the molecular formula $\mathrm{C}_{19} \mathrm{H}_{30} \mathrm{O}_{8} .400 \mathrm{MHz}{ }^{1} \mathrm{H}-$ NMR $\left(\mathrm{C}_{5} \mathrm{D}_{5} \mathrm{~N}\right): \delta 1.06(3 \mathrm{H}, \mathrm{s}, \mathrm{H}-13), 1.48(3 \mathrm{H}$, $\mathrm{s}, \mathrm{H}-11$ or $\mathrm{H}-12), 1.50(3 \mathrm{H}, \mathrm{s}, \mathrm{H}-11$ or $\mathrm{H}-12)$, $2.17(3 \mathrm{H}, \mathrm{s}, \mathrm{H}-10), 5.87(1 \mathrm{H}, \mathrm{s}, \mathrm{H}-8), 5.09(1 \mathrm{H}$, $\mathrm{d}, \quad J=7.6 \mathrm{~Hz}$, Glc-1). $100 \mathrm{MHz}{ }^{13} \mathrm{C}-\mathrm{NMR}$ $\left(\mathrm{C}_{5} \mathrm{D}_{5} \mathrm{~N}\right)$ as cited in Table 1 .

Evaluation of the effects of Digoxin, Cryptostigmin II and Cryptostegia extract on blood pressure and heart rate re, $^{6,7}$

Adult male rabbits (1.5-2.5 kg average weight) were used. The rabbits were anesthetized with intraperitoneal injection of $25 \%$ urethane solution in a dose of $6.4 \mathrm{ml} / \mathrm{kg}$. Their tracheae were cannulated for artificial respiration when necessary. The right femoral vein was cannulated for intravenous injection of the tested samples. The arterial blood pressure was recorded via the carotid artery which was connected to a PT 400 Blood Pressure Transducer and an amplifier of a twochannel oscillograph MD2 (Bioscience, Kent, UK). The transducer was then calibrated and the electrocardiographic changes were simultane-ously recorded using standard lead II. The changes in blood pressure and heart rate of rabbits were recorded before and at 15 ,
30, 60 and $90 \mathrm{~min}$ after intravenous injection of the different doses from the sample solution in normal saline. The obtained results are recorded in Tables 1 and 2.

Evaluation of the effects of Digoxin, Cryptostigmin II and Cryptostegia extract on the contractility of the isolated perfused rabbit's heart

The isolated hearts were prepared for perfusion according to Langendorff $(1895)^{7}$ as follows: the rabbits were injected with heparin (1000 units $/ \mathrm{kg}$ ) into the ear vein and $30 \mathrm{~min}$ later, the rabbits were sacrificed and the heart with at least $1 \mathrm{~cm}$ of attached aorta was removed as quickly as possible and placed in a dish of Lock-Ringer solution at $37^{\circ}$. The aorta was cut just below the point where it divides and the heart was transferred to the perfusion apparatus which contains two bottles, one for the unmedicated perfusion fluid and the second for the perfusion fluid that contains the required concentration of digoxin, Cryptostegia extract and cryptostigmin II. The aorta was tied onto the glass cannula and the perfusion fluid was an oxygenated lock. Ringer solution was warmed to $37^{\circ}$ by means of a water jaket adjusted at $38^{\circ}$.

Table 2: Time course of changes in the mean arterial blood pressure of rabbits receiving different dose levels of Digoxin, Cryptostegia extract and Cryptostigmin-II intravenously.

\begin{tabular}{|c|c|c|c|c|c|c|c|c|c|}
\hline \multirow{3}{*}{ Time } & \multicolumn{7}{|c|}{ Mean arterial blood pressure $(\mathrm{mmHg})$} \\
\cline { 2 - 10 } & \multicolumn{3}{|c|}{ Digoxin } & \multicolumn{3}{c|}{ Cryptostegia extract } & \multicolumn{3}{c|}{ Cryptostigmin II } \\
\cline { 2 - 10 } & $\begin{array}{c}0.5 \\
\mathrm{mg} / \mathrm{kg}\end{array}$ & $\begin{array}{c}1.0 \\
\mathrm{mg} / \mathrm{kg}\end{array}$ & $\begin{array}{c}1.5 \\
\mathrm{mg} / \mathrm{kg}\end{array}$ & $\begin{array}{c}2.5 \\
\mathrm{mg} / \mathrm{kg}\end{array}$ & $\begin{array}{c}5.0 \\
\mathrm{mg} / \mathrm{kg}\end{array}$ & $\begin{array}{c}7.5 \\
\mathrm{mg} / \mathrm{kg}\end{array}$ & $\begin{array}{c}0.5 \\
\mathrm{mg} / \mathrm{kg}\end{array}$ & $\begin{array}{c}1.0 \\
\mathrm{mg} / \mathrm{kg}\end{array}$ & $\begin{array}{c}1.5 \\
\mathrm{mg} / \mathrm{kg}\end{array}$ \\
\hline 0 & $105 \pm 7.5$ & $105 \pm 5.7$ & $105 \pm 3.4$ & $105 \pm 4.2$ & $105 \pm 2.7$ & $108 \pm 9.5$ & $105 \pm 4.8$ & $105 \pm 2.4$ & $100 \pm 5.3$ \\
\hline $\begin{array}{c}15 \\
\min \end{array}$ & $108 \pm 4.5$ & $110 \pm 2.4$ & $110 \pm 2.1$ & $105 \pm 2.6$ & $108 \pm 4.2$ & $110 \pm 2.1$ & $110 \pm 2.0$ & $100 \pm 8.6$ & $95 \pm 8.7$ \\
\hline $\begin{array}{c}30 \\
\text { min }\end{array}$ & $105 \pm 8.6$ & $105 \pm 8.2$ & $102 \pm 5.7$ & $105 \pm 2.8$ & $102 \pm 7.9$ & $105 \pm 3.7$ & $105 \pm 5.9$ & $110 \pm 2.1$ & $105 \pm 2.7$ \\
\hline $\begin{array}{c}60 \\
\min \end{array}$ & $105 \pm 7.0$ & $105 \pm 9.2$ & $104 \pm 4.6$ & $105 \pm 6.9$ & $103 \pm 9.1$ & $105 \pm 1.8$ & $110 \pm 9.8$ & $115 \pm 8.8$ & $105 \pm 8.2$ \\
\hline $\begin{array}{c}90 \\
\mathrm{~min}\end{array}$ & $105 \pm 6.5$ & $105 \pm 3.8$ & $102 \pm 6.8$ & $105 \pm 2.2$ & $105 \pm 3.5$ & $105 \pm 7.2$ & $110 \pm 4.6$ & $105 \pm 2.9$ & $105 \pm 3.8$ \\
\hline
\end{tabular}

Each figure represents the mean five experiments \pm standard error. 
The rate of flow of the perfusion fluid was kept constant at $3 \mathrm{ml} / \mathrm{min}$ by adjusting the pressure exerted on the fluid by means of a mercury manometer connected to the perfusion system. A thread was attached to the ventricle by a hook and the other end of the thread was passed over pulley wheels and was attached to the displacement transducer connected to the Oscillograph $4002 \mathrm{C}$. The contractions of the perfused hearts were recorded at a constant chart speed. Normal contraction was recorded during a period of $20 \mathrm{~min}$ until it was stabilized and become consistent. Then, the LockRinger's solution containing the definite concentrations of the investigated samples was started to perfuse the hearts and recording the myocardial contractility every $5 \mathrm{~min}$ for a period of $30 \mathrm{~min}$. The percentage change in the amplitude of normal myocardial contractility after perfusion with the tested samples was calculated. The results are given in Table 3 .

\section{Determination of the median lethal dose}

The median lethal dose $\left(\mathrm{LD}_{50}\right)$ and its $95 \%$ fiducial limits were calculated for Cryptostegia extract and cryptostigmin II. Groups of 6 male adult albino mice (20-28 g each) housed under the same conditions were intraperitoneally injected with graded doses of the extract (10 mg. $20 \mathrm{mg}$. $40 \mathrm{mg}$ and $80 \mathrm{mg}$ ) and cryptostigmin II ( $2 \mathrm{mg}, 3 \mathrm{mg}, 4 \mathrm{mg}$ and $8 \mathrm{mg}$ ). The mortality was determined 24 hours later in each group of the animals. Then the $\mathrm{LD}_{50}$ results $(\mathrm{mg} / \mathrm{kg})$ were recorded as follows: 21.37 \pm 3.52 for Cryptostegia extract and $5.75 \pm 0.82$ for cryptostigmin II.

\section{RESULTS AND DISCUSSION}

The ethanolic extract of the leaves of $C$. grandiflora was defatted with n-hexane and $\mathrm{CH}_{2} \mathrm{Cl}_{2}$ and the aqueous layer was subjected to a column chromatography of Diaion HP-20. The $40 \%$ methanol eluate was repeatedly chromatographed on columns of silica gel and HPLC to afford four glucosides (1-4).

${ }^{1} \mathrm{H}-\mathrm{NMR}$ spectrum of compound (1) showed one anomeric proton for $\beta$ glucopyranose at $\delta 4.96$, four $\mathrm{OCH}_{3}$ groups at $\delta$ 3.82 and the other signals are similar to those reported for Liriodendrin. ${ }^{8}{ }^{13} \mathrm{C}-\mathrm{NMR}$ spectrum revealed the presence of one anomeric carbon for $\beta$-glucopyranose at $102.9 \mathrm{ppm}$, four aromatic carbons at 104.7 and $104.8 \mathrm{ppm}$, and four methoxylated aromatic carbons at 153.9 ppm. ${ }^{13} \mathrm{C}-\mathrm{NMR}$ spectrum for the aglycone revealed the upfield shift of $\mathrm{C}-4$ ' and c-4", the upfield shifts of the other aromatic carbons and the other signals are very similar to those reported for (+)-syringaresinol. ${ }^{9}$ This compound was previously isolated from the bark of Eucommia ulmoides Oliv. (Eucommiaceae). ${ }^{10}$

Table 3: Time course of changes in the heart rate of rabbits receiving different dose levels of Digoxin, Cryptostegia extract and Cryptostigmin II intravenously.

\begin{tabular}{|c|c|c|c|c|c|c|c|c|c|}
\hline \multirow{3}{*}{ Time } & \multicolumn{9}{|c|}{ Heart rate (beat/min) } \\
\cline { 2 - 10 } & \multicolumn{3}{|c|}{ Digoxin } & \multicolumn{3}{c|}{ Cryptostegia extract } & \multicolumn{3}{c|}{ Cryptostigmin II } \\
\cline { 2 - 10 } & $\begin{array}{c}0.5 \\
\mathrm{mg} / \mathrm{kg}\end{array}$ & $\begin{array}{c}1.0 \\
\mathrm{mg} / \mathrm{kg}\end{array}$ & $\begin{array}{c}1.5 \\
\mathrm{mg} / \mathrm{kg}\end{array}$ & $\begin{array}{c}2.5 \\
\mathrm{mg} / \mathrm{kg}\end{array}$ & $\begin{array}{c}5.0 \\
\mathrm{mg} / \mathrm{kg}\end{array}$ & $\begin{array}{c}7.5 \\
\mathrm{mg} / \mathrm{kg}\end{array}$ & $\begin{array}{c}0.5 \\
\mathrm{mg} / \mathrm{kg}\end{array}$ & $\begin{array}{c}1.0 \\
\mathrm{mg} / \mathrm{kg}\end{array}$ & $\begin{array}{c}1.5 \\
\mathrm{mg} / \mathrm{kg}\end{array}$ \\
\hline 0 & $310 \pm 26$ & $300 \pm 24$ & $300 \pm 20$ & $290 \pm 25$ & $280 \pm 18$ & $280 \pm 22$ & $280 \pm 20$ & $290 \pm 15$ & $300 \pm 28$ \\
\hline $\begin{array}{c}15 \\
\mathrm{~min}\end{array}$ & $310 \pm 20$ & $240 * \pm 20$ & $220 * \pm 18$ & $300 \pm 22$ & $275 \pm 20$ & $220^{*} \pm 20$ & $290 \pm 22$ & $290 \pm 20$ & $260^{*} \pm 25$ \\
\hline $\begin{array}{c}30 \\
\min \end{array}$ & $310 \pm 22$ & $230 * \pm 18$ & $210^{*} \pm 20$ & $300 \pm 25$ & $275 \pm 25$ & $220^{*} \pm 18$ & $290 \pm 26$ & $290 \pm 20$ & $260^{*} \pm 22$ \\
\hline $\begin{array}{c}60 \\
\mathrm{~min}\end{array}$ & $310 \pm 25$ & $230 * \pm 20$ & $220 * \pm 16$ & $290 \pm 28$ & $280 \pm 24$ & $240^{*} \pm 20$ & $290 \pm 24$ & $290 \pm 23$ & $240^{*} \pm 20$ \\
\hline $\begin{array}{c}90 \\
\text { min }\end{array}$ & $310 \pm 18$ & $230 * \pm 20$ & $220 * \pm 21$ & $290 \pm 24$ & $280 \pm 23$ & $240^{*} \pm 22$ & $290 \pm 20$ & $290 \pm 15$ & $260^{*} \pm 24$ \\
\hline \hline
\end{tabular}

Each figure represents the mean five experiments \pm standard error.

* Significant difference $(\mathrm{P}<0.01)$ Vs control values. 
${ }^{1} \mathrm{H}-\mathrm{NMR}$ spectrum for compound (2) showed multiplet signal at $\delta 5.41$ for $2 \mathrm{H}$ at positions 2 and 3; quartet signal at $\delta 1.91 \mathrm{~J}=$ $7.2 \mathrm{~Hz}$ for $2 \mathrm{H}$ at positions 4 and 5, triplet signal at $\delta 0.81 J=7.6 \mathrm{~Hz}$ for $3 \mathrm{H}$ at position 6 and a doublet signal at $\delta 4.84, J=7.8 \mathrm{~Hz}$ for anomeric proton.

The ${ }^{13} \mathrm{C}$-NMR spectrum revealed the presence of twelve carbon atoms, six of them were at $\delta 104.7,75.2,78.5,71.7,78.6$ and 62.8 which are characterisitc for $\beta$-glucopyranoside and the other six carbon atoms were characteristic for the presence of olefinic carbons between $\mathrm{C}-3$ and $\mathrm{C}-4$ at $\delta 133.5$ and 125.5 , in addition to oxygenated methine carbon at $\delta 69.3$ corresponding to $\mathrm{C}-1$ and at $\delta$ 20.8 corresponding to $\mathrm{C}-5$ and one signal for methyl group at $\delta 14.3 \mathrm{ppm}$. It can be concluded that the structure is in full agreement with that reported for (Z)-3-hexenyl $\beta$-D-glucopyranoside. $^{11}$

The molecular formula of compound 3 was deduced as $\mathrm{C}_{19} \mathrm{H}_{20} \mathrm{O}_{9}$ from HR FAB-MS spectrometry (see experimental section). The ${ }^{13} \mathrm{C}$-NMR spectrum and DEPT experiment of $\mathbf{3}$ (Table 1) displayed the presence of one unsubstituted $\beta$-glucopyranosyl unit from the signals at $\delta_{\mathrm{C}} 100.7\left(\mathrm{C}-1^{\prime \prime}\right), 73.2\left(\mathrm{C}-2{ }^{\prime \prime}\right), 76.6$ (C-3“), 69.5 (C-4“), 77.1 (C-5") and 60.7 (C$\left.6^{\prime \prime}\right)$ together with 7 methines $\left(\delta_{\mathrm{C}} 132.5,129.0\right.$ for 2 carbons, 128.3 for 2 carbons, 96.7 and $94.3)$ and 6 quaternary carbon signals $\left(\delta_{C}\right.$ $194.9,160.3,157.1,157.0,108.7$ and 138.7) for the aglycone. The two chemically equivalent methines at $\delta_{\mathrm{C}} 129.0\left(\mathrm{C}-3^{\prime}, 5^{\prime}\right)$ as well as those at $\delta_{\mathrm{C}} 128.3\left(\mathrm{C}-2{ }^{\prime}, 6^{\circ}\right)$ together with the methine at $\delta_{\mathrm{C}} 132.5\left(\mathrm{C}-4^{\prime}\right)$ suggested a presence of monosubstituted benzene. ${ }^{12}$ From ${ }^{1} \mathrm{H}-\mathrm{NMR}$ spectrum of $\mathbf{3}$, the multiplet signal at $\delta_{\mathrm{H}} 7.56$ for one proton $(\mathrm{H}-4)$ together with the two multiplets for two pairs of chemically equivalent protons at $\delta_{\mathrm{H}} 7.45\left(\mathrm{H}-2{ }^{`}, 6^{`}\right)$ and 7.70 $\left(\mathrm{H}-3^{\prime}, 5^{\circ}\right)$ confirmed the presence of a monosubstituted benzene. On the other hand the three quaternary carbons at $\delta_{\mathrm{C}} 160.3(\mathrm{C}-4)$, 157.1 (C-6) and 157.0 (C-2) were assigned for three oxygenated aromatic carbons due to their downfield shifts. ${ }^{13}$ In the ${ }^{1} \mathrm{H}-\mathrm{NMR}$ spectrum of 3 , the two doublets at $\delta_{\mathrm{H}} 6.07$ (H-5) and 6.15 (H-3) with a coupling constant $1.9 \mathrm{~Hz}$ each, indicated the presence of two meta coupled aromatic protons. This was confirmed from the two methine carbons at $\delta 94.3$ (C-3) and 96.7 (C-5) in the ${ }^{13} \mathrm{C}$-NMR spectrum. Therefore the second benzene ring was determined as tetrasubstituted benzene. Moreover, The quaternary carbon signal at $\delta 194.9$ was very clear for a ketonic carbonyl connecting the two benzene rings that was confirmed from the two quaternary carbons at $\delta 108.7(\mathrm{C}-1)$ and 138.7 $\left(\mathrm{C}-1^{\prime}\right)$ in the ${ }^{13} \mathrm{C}-\mathrm{NMR}$ spectrum. Therefore, the aglycone of $\mathbf{3}$ was identified as 2, 4, 6trihydroxybenzophenone. In the ${ }^{1} \mathrm{H}-\mathrm{NMR}$ spectrum of $\mathbf{3}$, the doublet signal at $\delta 4.74$ with $\mathrm{J}$ (constant) $7.6 \mathrm{~Hz}$ for the anomeric proton of the glucosyl residue indicated its $\beta$ configuration. The attachment of the glucopyranosyl unit to C-2 of the aglycone was esablished by $2 \mathrm{D}$ NMR spectral analyses. The HMQC spectral data of $\mathbf{3}$ revealed the correlations between each carbon and its directly attached protons while $\mathrm{H}-\mathrm{H}$ COSY interpreted the proton-proton couplings. The HMBC spectral analysis of $\mathbf{3}$ (Fig. 1) displayed significant correlation peaks between $\mathrm{H}-3,5,2$, $3,5,6$ and $\mathrm{C}=\mathrm{O} ; \mathrm{H}-3,5$ and $\mathrm{C}-1$; H-6, 2 and $\mathrm{C}-1^{1}$ as well as between $\mathrm{H}-1$ of the glucopyranosyl moiety and C-2 of the aglycone. Consequently, the structure of compound 3 was identical to that of $2,4,6-$ trihydroxybenzo-phenone 2-O- $\beta$ glucopyranoside. ${ }^{14,15}$ This is the first report for ${ }^{1} \mathrm{H}-,{ }^{13} \mathrm{C}-$, 2D NMR and HR-FAB-MS spectral data for compound 3 .

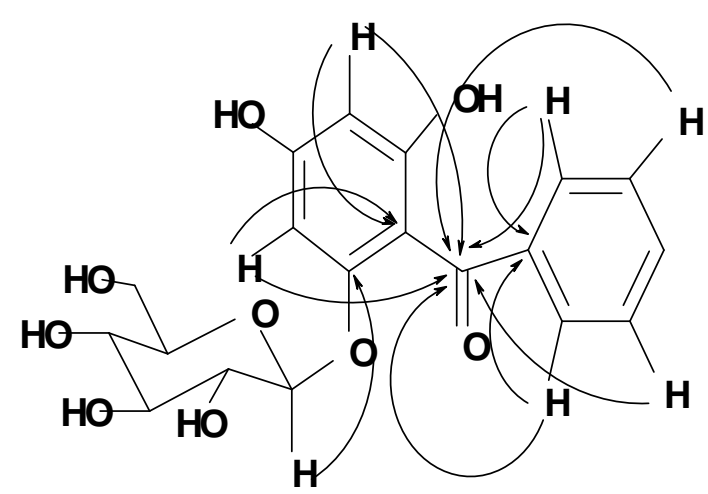

Fig. 1: Significant HMBC correlations of compound $\mathbf{3}$

The ${ }^{1} \mathrm{H}-\mathrm{NMR}$ spectrum of compound (4) exhibited four singlet methyl signals at $\delta 1.06$ $(3 \mathrm{H})$ at $13,1.48(3 \mathrm{H})$ at 11 or $12,1.50(3 \mathrm{H})$ at 11 or 12 and $2.17(3 \mathrm{H})$ at 10 , the last one being due to a methyl ketone. An anomeric proton 
signal at $\delta 5.09(1 \mathrm{H}, \mathrm{d}, J=7.6 \mathrm{~Hz})$ and an olefinic proton signal at $\delta 5.87(1 \mathrm{H}, \mathrm{s})$ at 8 .

${ }^{13} \mathrm{C}$-NMR spectrum showed the presence of two carbinol carbon signals at 71.8 (d) and 71.2 (s). The former was shifted downfield by $6.2 \mathrm{ppm}$ in ${ }^{13} \mathrm{C}$-NMR spectrum of the aglycone and the later shifted downfield by only 1.0 ppm., this indicated the presence of glucosidation at position C-3.

These results led us to conclude that, the structure is in full agreement with that reported for Icariside $\mathrm{B}_{1}{ }^{16,17}$

The structure determination was based on comparison of their physical chemical and spectral data $\left({ }^{1} \mathrm{H},{ }^{13} \mathrm{C}-\mathrm{NMR}\right.$ and FAB-MS $)$ with those reported for acanthoside $\mathrm{B},(\mathrm{Z})$-3-hexenyl B-D-glucopyranodside, 2,4,6-trihydroxybenzophenone 2-O- $\beta$-Glucopyranoside and icariside $\mathrm{B}_{1}$.

The cardiotonic activity of Cryptostigmin II, the major cardenolide previously isolated from the leaves of $C$. grandiflora as well as the plant extract were investigated in comparison with digoxin. From the data reported in Table 2 , the intravenous administration of different doses of digoxin, C. grandiflora extract and Cryptostigmin II showed no change in the arterial blood pressure during the period of investigation $(90 \mathrm{~min})$. On the other hand, the intravenous administration of digoxin in doses of 1.0 and $1.5 \mathrm{mg} / \mathrm{kg}$ decreased the heart rate of rabbits. This reduction was started after $15 \mathrm{~min}$ of administration (Table 3). From the results reported in the same Table, no change in the heart rate was observed after administration of the extract in doses of 2.5 and $5 \mathrm{mg} / \mathrm{kg}$ but the decrease in the heart rate was obvious at a dose of $7.5 \mathrm{mg} / \mathrm{kg}$ of the extract after $15 \mathrm{~min}$ of the intravenous administration. Moreover, no change in the heart rate was observed with doses of 0.5 and $1.0 \mathrm{mg} / \mathrm{kg}$ of Cryptostigmin II, but a significant decrease in the heart rate was clear when the dose increased to $1.5 \mathrm{~m} / \mathrm{kg}$ after 15 min of administration. On the other hand, recording the contractility of the isolated perfused rabbit's heart every $5 \mathrm{~min}$ for a period of $30 \mathrm{~min}$ showed that digoxin produced no change at a concentration level of $0.25 \mathrm{mg} / \mathrm{ml}$ while the increase in the contractility was observed when the concentration levels were inreased to 0.5 and $1.0 \mathrm{mg} / \mathrm{ml}$ during the investigation period (Table 4). From the same Table, it's evident that the extract didn't exhibit any effect on the contractility at a concentration level of $2.5 \mathrm{mg} / \mathrm{ml}$ while it increased the contractility significantly when the concentration levels were increased to 5.0 and $7.5 \mathrm{mg} / \mathrm{ml}$ Cryptostigmin II revealed significant increase in the contractility at a concentration level of $1 \mathrm{mg} / \mathrm{ml}$ that is more potent than that of digoxin at the same concentration level after 15 and $30 \mathrm{~min}$ of administration.

Table 4: Effect of different concentrations of Digoxin, Cryptostegia extract and Cryptostigmin II on the contractility of the isolated rabbit's heart at different time intervals.

\begin{tabular}{|c|c|c|c|c|c|c|c|c|c|}
\hline \multirow{3}{*}{ Time } & \multicolumn{6}{|c|}{ Contractility (\% of change from control) } \\
\cline { 2 - 10 } & \multicolumn{3}{|c|}{ Digoxin } & \multicolumn{2}{c|}{ Cryptostegia extract } & \multicolumn{3}{c|}{ Cryptostigmin II } \\
\cline { 2 - 10 } & $\begin{array}{c}0.25 \\
\mathrm{mg} / \mathrm{ml}\end{array}$ & $\begin{array}{c}0.5 \\
\mathrm{mg} / \mathrm{ml}\end{array}$ & $\begin{array}{c}1.0 \\
\mathrm{mg} / \mathrm{ml}\end{array}$ & $\begin{array}{c}2.5 \\
\mathrm{mg} / \mathrm{ml}\end{array}$ & $\begin{array}{c}5.0 \\
\mathrm{mg} / \mathrm{ml}\end{array}$ & $\begin{array}{c}7.5 \\
\mathrm{mg} / \mathrm{ml}\end{array}$ & $\begin{array}{c}0.5 \\
\mathrm{mg} / \mathrm{ml}\end{array}$ & $\begin{array}{c}1.0 \\
\mathrm{mg} / \mathrm{ml}\end{array}$ & $\begin{array}{c}1.5 \\
\mathrm{mg} / \mathrm{ml}\end{array}$ \\
\hline $\begin{array}{c}5.0 \\
\mathrm{~min}\end{array}$ & 2.0 & $22^{*} \pm 2.1$ & $30^{*} \pm 2.8$ & 2.0 & $50^{*} \pm 4.2$ & $25^{*} \pm 1.2$ & 2.0 & $27^{*} \pm 1.8$ & $20^{*} \pm 1.8$ \\
\hline $\begin{array}{c}10 \\
\min \end{array}$ & 2.0 & $34^{*} \pm 3.0$ & $40^{*} \pm 3.7$ & 2.0 & $57^{*} \pm 3.8$ & $37^{*} \pm 2.2$ & 2.0 & $43^{*} \pm 2.8$ & $30^{*} \pm 2.8$ \\
\hline $\begin{array}{c}15 \\
\min \end{array}$ & 3.0 & $33^{*} \pm 2.8$ & $50^{*} \pm 4.5$ & 2.5 & $96^{*} \pm 7.2$ & $42^{*} \pm 3.1$ & 3.0 & $66^{*} \pm 5.2$ & $35^{*} \pm 2.9$ \\
\hline $\begin{array}{c}30 \\
\min \end{array}$ & 3.0 & $33^{*} \pm 3.1$ & $50^{*} \pm 4.5$ & 3.0 & $96^{*} \pm 8.1$ & $42^{*} \pm 3.8$ & 3.0 & $66^{*} \pm 4.6$ & $35^{*} \pm 2.1$ \\
\hline
\end{tabular}

Each figure represents the mean five experiments \pm standard error.

* Significant difference $(\mathrm{P}<0.01)$ Vs control values. 


\section{ACKNOWLEDGMENTS}

The authors are grateful to the Japan Society for Promotion of Science (JSPS) and a Grant-in-Aid, Ministry of Education and Culture, Japan for the financial support of a part of this work. Also, we would like to thank the Research Center of Molecular Medicine of the Hiroshima University School of Medicine, Japan, for NMR measurements and Prof. Dr. Ahmed O. Abdel-Zaher, Dept. of Pharmacology, Faculty of Medicine, Assiut Univ. for his valuable comments on the biological results of this work.

\section{REFERENCES}

1- C. Metcalf and L. Chalk, The Clarendon Press, Oxford, Vol. II., p. 917 (1950).

2- R. Chopra, R. Badhwar and S. Ghosh, Indian Council of Agricultural Research, India, Vol. I., p. 577-78 (1965).

3- J. Hutchinson, The Clarendon Press, Third edition The Clarendon Press Oxford, p. 472, (1973).

4- J. Watt and M. Breyer, Livingstone, London, p. 69 (1962).

5- M. Kamel, M. Assaf, Y. Abe, K. Ohtani, R. Kasai and K. Yamasaki, Phytochemistry, 58, 537-42 (2001)

6- A. Bass, J. Kohli, N. Lubbers and L. Goldgberg, J. Pharmacol. Exp. Ther., 242, 940-944 (1987).

7- O. Langendorff (1895), c.f. Pharmacological Experiments on Isolated Preparation. E. and S. Livingston, Edinbeurgh and London (1970).
8- M. S. Tempesta and R. B. Bate, J. Org. Chem, 45, 1327 (1980).

9- S. Omori and A. Sakakibara, Mokuzai Gakkaishi, 20, 388 (1974), H. Fujimoto and T. Higucki, ibid., 23, 405 (1977), Byug Ho Hwang and A. Sakakibara, ibid., 25, 647 (1979).

10- T. Deyama, Chem. Pharm. Bull., 31 (9), 2993-2997 (1983).

11- K. Yoshikawa, k. Eiko, N. Mimura, Y. Kondo, S. Arihara and G. C. Hovetrichosides, J. Nat. Prod., 61, 786790 (1998).

12- R. M. Silverstein and G. C. Bassler, Spectrometric Identification of Organic Compounds, John Wiley \& sons Inc., New York, London, Sydney, $10^{\text {th }}$ Ed. (1998).

13- E. Breitmaier and W. Voelter, Carbon-13 NMR Spectorscopy, $3^{\text {rd }}$ Ed. Verlagsgesellschaft $\mathrm{mbH}$, Weinheim, Germany D-6940 (1987).

14- K. Nagumo, K. Kawai, H. Nagase, T. Inoue and M. Nagai, Yakugaku Zasshi, 104, 1223-1231 (1984).

15- O. Gottlieb, W. Mors, J. Am. Chem. Soc., 80, 2263 (1958).

16- T. Miyase, A. Ueno, N. Takizawa, H. Kobayashi and H. Karasawa, Chem. Pharm. Bull., 35, 1109-1117 (1987).

17- J. Meinwald, K. Erickson, M. Hartshron and T. Eisner, Tetrahedron Lett., 2959, (1968), S. Isoe, S. Katsumura, S.B. Hyeon and T. Sakan, ibid., 1089 (1971). 